PARRACHA J.L., LIMA J., FREIRE M.T., FERREIRA M., FARIA P. Vernacular Earthen Buildings from Leiria, Portugal: Material characterization. International Journal of Architectural Heritage.Int. J. Architectural Heritage, https://doi.org/10.1080/15583058.2019.1668986

\title{
Vernacular Earthen Buildings from Leiria, Portugal - Material Characterization
}

João Luís Parracha ${ }^{\mathrm{a}, \mathrm{b}}$, José Lima $^{\mathrm{c}}$, Maria Teresa Freire ${ }^{\mathrm{d}, \mathrm{e}}$, Micael Ferreira ${ }^{\mathrm{a}}$, Paulina Faria ${ }^{\mathrm{a}, \mathrm{e}^{*}}$ a Department of Civil Engineering, Faculty of Science and Technology, NOVA University of Lisbon, Caparica, Portugal; ${ }^{\mathrm{b}}$ Department of Structures, National Laboratory for Civil Engineering, Lisbon, Portugal; ${ }^{c}$ Faculty of Architecture, University of Lisbon, Lisbon, Portugal; ${ }^{\mathrm{d}}$ Department of Materials, National Laboratory for Civil Engineering, Lisbon, Portugal; ${ }^{\mathrm{e}} \mathrm{CERIS}$, Civil Engineering Research and Innovation for Sustainability, Instituto Superior Técnico, Lisbon, Portugal.

*Corresponding author: Paulina Faria, CERIS and Department of Civil Engineering, Faculty of Science and Technology, NOVA University of Lisbon, 2829-516, Caparica, Portugal; E-mail: paulina.faria@fct.unl.pt

\begin{abstract}
In Portugal a large number of vernacular earthen buildings present an advanced state of degradation. These buildings comprise historical, technological, architectonic, cultural and social recognized values and, therefore, efficient interventions are needed for their conservation. The knowledge of the properties that the materials used in their construction show nowadays is one of the bases to support future interventions. Unstabilized earthen samples were collected from the walls of six earthen buildings located in the region of Leiria, Portugal, built with rammed earth and/or adobe masonry. The samples were characterized by particle size distribution and through XRD, density, capillary, drying, dry abrasion, tensile and compressive flexural strength. Mechanical results of rammed earth were lower than adobe's, contrary to what was commonly found in other studies, and capillary coefficients of adobe were comparable to lime stabilized adobe from other regions. A surface protection by compatible renders,
\end{abstract}


respectively earthen-based and air lime-based, is strongly encouraged to extend the walls durability. Although based on a short sampling, this data gives initial support to future compatible, effective and reversible interventions in Leiria vernacular earthen buildings, contributing to the preservation of this earth-built heritage.

Keywords: adobe masonry; earth construction; laboratory characterization; rammed earth; sustainable construction; vernacular architecture.

\section{Introduction}

The conservation and preservation of the built heritage is an important public and political concern. The use of earth as construction material was very common until the middle of the twentieth century, being rammed earth and adobe masonry the most widespread and important construction techniques (Houben and Guillaud, 1994), namely in Portugal (Costa et al., 2018). Furthermore, in periods dating back from the twelfth century many fortresses were built with earth as the main construction material, such as the castles of Paderne and Silves, fortifications that are still part of the country military rammed earth-built heritage (Correia, 2004; Parracha et al., 2019).

For rammed earth vernacular construction, locally excavated earth was roughly disaggregated, sprayed with some water just to be moistened, successively placed in layers of about $20 \mathrm{~cm}$ height inside a wooden formwork and compacted vertically with a manual wooden mallet, reducing height (Maniatidis and Walker, 2003). Coarse stone existing in the excavated earth was generally used; the only concern was that bigger elements that were manually placed in the interior of the wall thickness would not be left close to the wall surfaces. It was not frequent to add air lime or other materials to the earth on vernacular constructions. Conversely, the addition of lime to the earth was quite frequent in military earth constructions (Parracha et al. 2019). The formwork, defining the walls thickness (not less than $40 \mathrm{~cm}$ ) and the rammed earth block length (generally between 1.5-2.0 m long), was filled with layers of earth to be compacted, up to its 
complete filling, producing a rammed earth wall parcel or block. Afterwards, the formwork was immediately disassembled and assembled again to produce the adjacent rammed earth block - in the same wall level or in the upper level, if the lower level was complete. The joints between adjacent rammed earth blocks in the same level could be vertical or diagonal. Before starting to build the adjacent block, joint materials could be placed (although not essential), such as an air lime mortar layer or red ceramic or laminar stone pieces. This vernacular technique, with some occasional adaptations, is still used nowadays in Portugal (Figure 1).

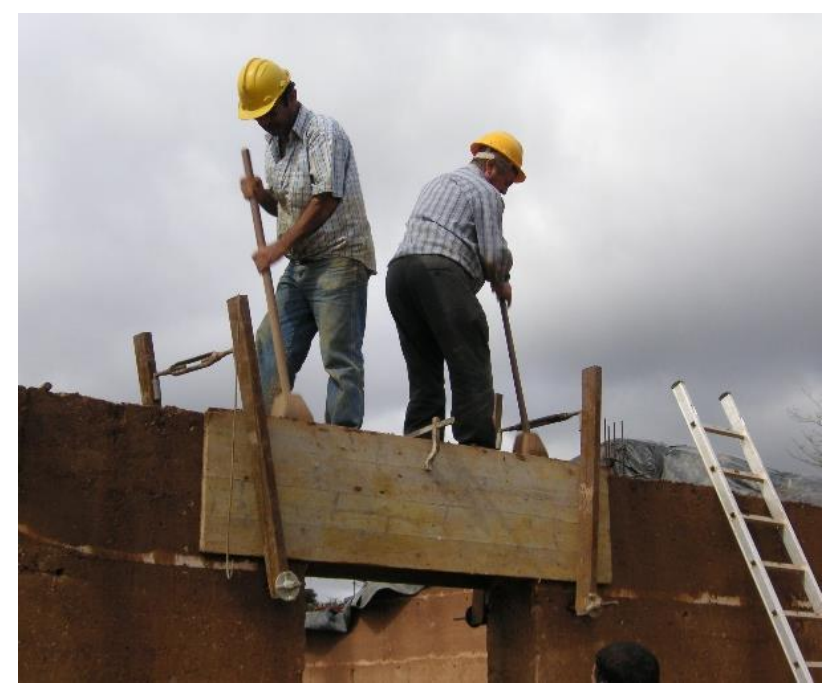

Figure 1 - Vernacular rammed earth formwork and manual compaction applied in a contemporary construction in Cercal, Alentejo, Portugal

For vernacular adobe production, traditional wooden molds (Figure 2) were filled with an earthen plastic mortar made with local earth, previously sieved to remove coarse stone particles. Leiria region is known for the production of pine wood. This wood was used for the production of both the adobe molds and the rammed earth formworks. The earth could be used either unstabilized or stabilized with the addition of air lime (if it had lack of clay), sand or plant fibres (if it was too clayey). The adobes were precast in advance, i.e., they were produced previously to the masonry construction to have time to dry. In comparison with rammed earth, a larger quantity of water was necessary to produce adobe and, later, the masonry layering mortar in order to build the adobe masonry wall. The masonry layering mortar could be similar to the adobe mortar 
(except that it would not have fibres), could be a mix of earth and air lime or could be an air lime mortar.

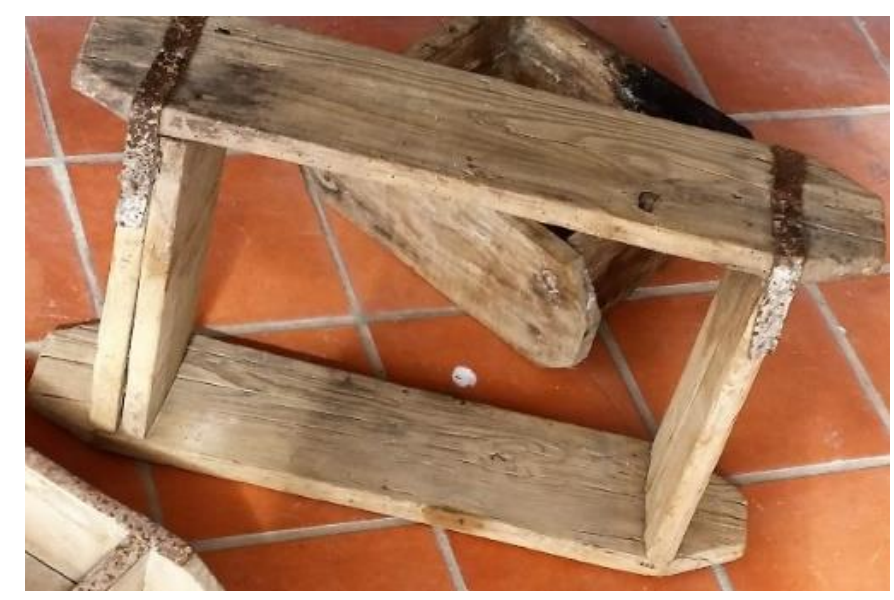

Figure 2. Wooden mold used for vernacular adobe production

The rammed earth walls could be coated or not. However, it was common to apply a render at least after one year so that the surface previously in contact with the formwork became rough; it also allowed to delay the investment in the render. Contrary to rammed earth, that could be maintained without rendering for some time, adobe masonry walls should be immediately protected by a render to avoid degradation (Faria-Rodrigues, 2005). Renders for both vernacular techniques were made with the same type of mortars defined for masonry layering. Frequently, only the render finishing layer was lime-based, being the base layer a mix of earth (which included the needed aggregate) and air lime.

With the introduction of new materials and techniques in current constructions (e.g. with the development of cement industry), earth construction suffered a decline during the first half of the twentieth century (McHenry, 1989). In the last decades, the use of earth materials for buildings has been regaining strength, mostly due to its recognized eco-efficiency, abundance and contribution to acoustic and hygrothermal performance (Allinson and Hall, 2010; Hamard et al., 2016).

Nevertheless, the existence of several earthen buildings that present an advanced state of degradation due to insufficient maintenance and conservation actions over time, or inappropriate 
interventions, is a concerning reality. To deal with this problem, it is paramount to gather information about the constructive technologies and materials used at the time of construction but also to know the properties of these materials nowadays. This data will constitute a crucial supporting tool, not only for future interventions in earthen buildings, but also for the design of new earth constructions.

Results from previous studies on adobe and rammed earth in Portugal, found in the literature, are summarized in Table 1.

Table 1. Results of density, tensile and compressive strengths from literature for adobe and rammed earth samples collected in Portugal, or replicated in laboratory

\begin{tabular}{|c|c|c|c|c|c|c|}
\hline Reference & Location & Sample & Typology & $\begin{array}{l}\text { Density } \\
\left(\mathrm{kg} / \mathrm{m}^{\mathbf{3}}\right)\end{array}$ & \begin{tabular}{|l|} 
Compressive \\
strength \\
$\left(\mathbf{N} / \mathbf{m m}^{2}\right)$ \\
\end{tabular} & $\begin{array}{l}\text { Tensile } \\
\text { strength } \\
\left(\mathrm{N} / \mathrm{mm}^{2}\right) \\
\end{array}$ \\
\hline $\begin{array}{l}\text { Figueiredo et al. } \\
\text { (2013) }\end{array}$ & Aveiro & - & \multirow{21}{*}{$\begin{array}{l}\text { Air lime } \\
\text { stabilized } \\
\text { adobe }\end{array}$} & - & 0.46 & 0.15 \\
\hline \multirow{8}{*}{ Silveira et al. (2012) } & \multirow[t]{8}{*}{ Aveiro } & H_01 & & \multirow{8}{*}{ - } & 1.24 & 0.13 \\
\hline & & H_02 & & & 1.00 & 0.19 \\
\hline & & H_03 & & & 0.75 & 0.19 \\
\hline & & H_04 & & & 0.66 & - \\
\hline & & H_05 & & & 2.15 & - \\
\hline & & H_09 & & & 0.70 & - \\
\hline & & H_10 & & & 1.98 & - \\
\hline & & H_11 & & & 1.08 & - \\
\hline \multirow[t]{6}{*}{ Silveira et al. (2013) } & \multirow[t]{6}{*}{ Aveiro } & H12_a03 & & \multirow[t]{3}{*}{1652} & 1.02 & - \\
\hline & & H12_a06 & & & 1.21 & - \\
\hline & & H12_a08 & & & - & 1.03 \\
\hline & & H13_a01 & & \multirow[t]{2}{*}{1530} & - & 0.20 \\
\hline & & H13_a10 & & & 0.28 & - \\
\hline & & H20_a07 & & 1540 & 0.23 & - \\
\hline \multirow[t]{4}{*}{ Coroado et al. (2010) } & \multirow[t]{4}{*}{ Aveiro } & MP11 & & \multirow{4}{*}{ - } & 0.51 & - \\
\hline & & CS1 & & & 0.25 & - \\
\hline & & TM1 & & & 1.44 & - \\
\hline & & LMM3 & & & 0.41 & - \\
\hline \multirow[t]{2}{*}{ Costa et al. (2013) } & \multirow{2}{*}{$\begin{array}{l}\text { Anadia and } \\
\text { Murtosa }\end{array}$} & Anadia & & \multirow{2}{*}{ - } & 2.52 & - \\
\hline & & Murtosa & & & 1.76 & - \\
\hline \multirow[t]{3}{*}{ Gomes et al. (2019) } & \multirow[t]{3}{*}{ Alentejo } & $\mathrm{Av}$ & \multirow{5}{*}{$\begin{array}{l}\text { Unstabilized } \\
\text { RE }\end{array}$} & 2222 & - & - \\
\hline & & $\mathrm{PD}$ & & 2008 & - & - \\
\hline & & $\mathrm{VC}$ & & 2089 & - & - \\
\hline \multirow[t]{2}{*}{ Mateus et al. (2014) } & \multirow{2}{*}{$\begin{array}{l}\text { Western } \\
\text { Algarve }\end{array}$} & Sesmarias & & \multirow[b]{2}{*}{ - } & 1.10 & - \\
\hline & & Arão & & & 1.30 & - \\
\hline
\end{tabular}




\begin{tabular}{|c|c|c|c|c|c|c|}
\hline & & $\begin{array}{l}\text { Montes de } \\
\text { Cima }\end{array}$ & & & 0.80 & - \\
\hline & & Pincho & & & 1.30 & - \\
\hline & & Porches & & & 2.70 & - \\
\hline Silva et al. (2018) & Esposende & - & & 1723 & 1.00 & - \\
\hline Silva et al. (2016) & Odemira & A & laboratory & 1802 & 1.26 & 0.22 \\
\hline & & $\mathrm{B}$ & & 1789 & 1.20 & 0.17 \\
\hline Faria et al. (2012) & Serpa & A & & 1905 & - & - \\
\hline & & A sieved & & 2003 & - & - \\
\hline & & $\mathrm{B}$ & & 1942 & - & - \\
\hline & & $\mathrm{B}+\mathrm{hl}$ & Stabilized & 1950 & - & - \\
\hline & & $\mathrm{B}+\mathrm{c}$ & RE & 1876 & - & - \\
\hline & & $\mathrm{C}+\mathrm{hl}$ & $\begin{array}{l}\text { laboratory } \\
\text { renlicas }\end{array}$ & 1846 & - & - \\
\hline & & $\mathrm{D}+\mathrm{hl}$ & & 1874 & - & - \\
\hline & & $\mathrm{D}+\mathrm{hl}+\mathrm{c}$ & & 1990 & - & - \\
\hline
\end{tabular}

Notation: RE - rammed earth; for each technique, regions are listed from North to South of Portugal.

No material data for Leiria earthen vernacular constructions was found in the literature. Nevertheless, in a previous paper (Ferreira et al., 2017), an extensive building technology and architectural survey of ninety-eight vernacular earthen buildings from the region of Leiria, Portugal, was presented and two of these buildings were taken as case studies. During that survey it was possible to identify:

- buildings with rammed earth walls, mainly located in Pombal municipality, buildings with adobe masonry walls mainly in Leiria municipality and also buildings with walls presenting both techniques, being in that case the adobe masonry mainly used to increase the walls' height and the area of the building;

- some construction specificities of these buildings, e.g. the existence of a vertical indentation in the adobe used for structural exterior walls (Figure 3);

- the dimensions of rammed earth blocks and adobe contrast with those found in other regions of Portugal: in Leiria district rammed earth blocks varied between $2.00 \mathrm{~m} \times 0.60$ $0.70 \mathrm{~m} \times 0.40-0.50 \mathrm{~m}$ (length $\times$ height $\times$ width/thickness $)$ and adobe dimensions varied between $0.30-0.46 \mathrm{~m} \times 0.14-0.30 \mathrm{~m} \times 0.12-0.16 \mathrm{~m}$ (length $\times$ width $\times$ height $)$. The adobe used for structural walls was placed with the higher dimension defining the wall thickness; 
- the most common anomalies associated to those buildings were due to the natural aging process of materials and the implementation of inadequate conservation interventions in the past, with the direct application of incompatible solutions in the adobe masonry and rammed earth walls.
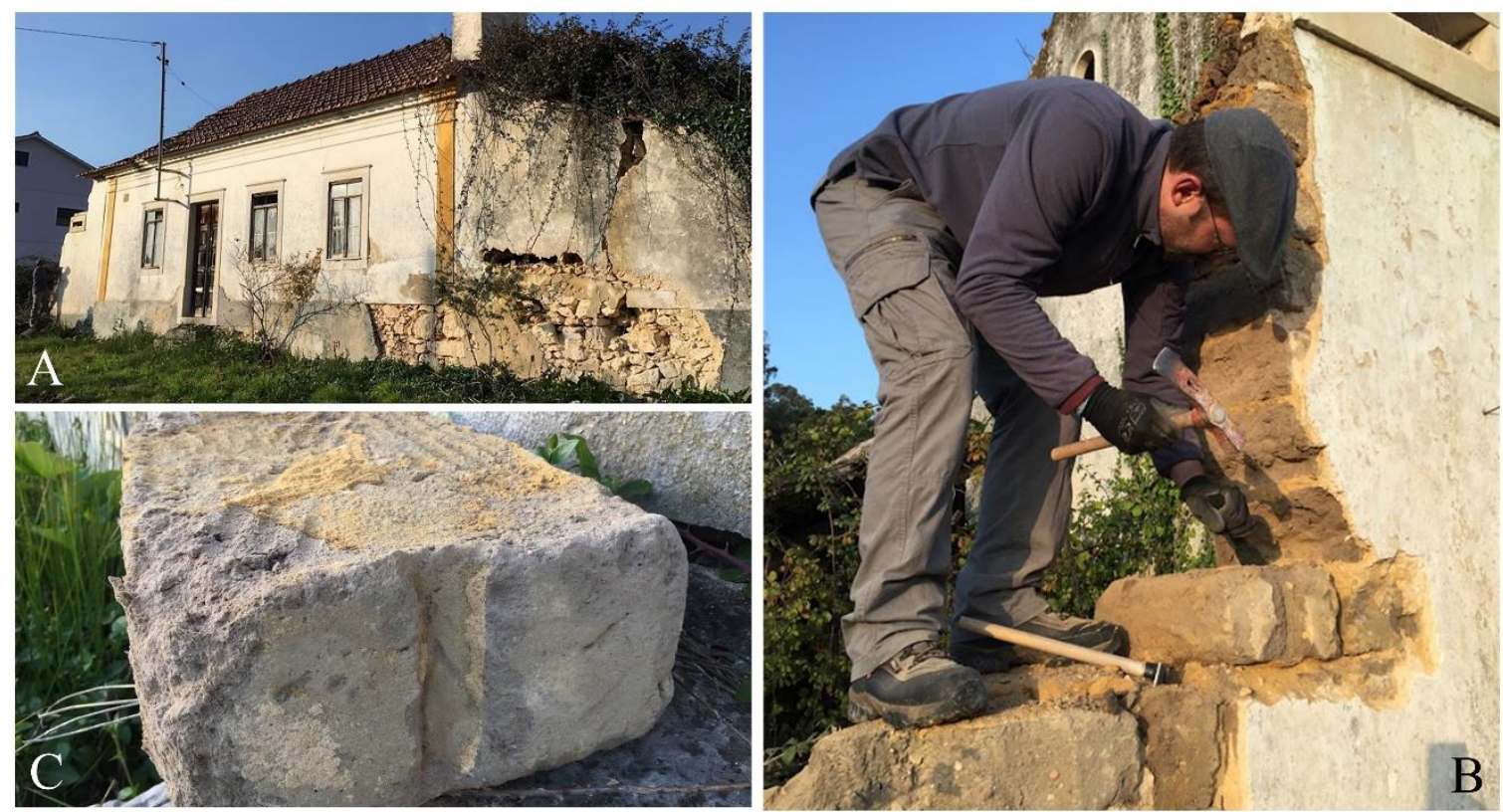

Figure 3. Adobe masonry dwelling from Leiria, Portugal (A); adobe samples being collected from a wall of the dwelling in A (B); detail of the adobe indentation (C)

In the present paper, the characterization results of eleven earth samples collected from six vernacular earthen buildings, belonging to the survey made in Leiria district, are presented and discussed. They are also analyzed and compared with the results of previous studies on adobe and rammed earth from another regions in Portugal (Table 1). The aim is to contribute to produce knowledge that can be used in the design of compatible solutions towards the conservation of this built heritage.

\section{Materials and methods}

\subsection{Buildings and samples}

For this experimental campaign, eleven original earth samples (OES) (six from adobe and five from rammed earth) were collected from six of the ninety-eight buildings previously inspected 
(Ferreira et al., 2017). The ninety-eight inspected buildings are located throughout the municipalities of Leiria and Pombal, in Leiria district. Twenty-four of those buildings are rammed earth constructions, sixty have adobe masonry and fourteen present both construction techniques.

The six buildings were selected considering: the construction technique - three buildings where it was possible to collect adobe and three buildings where it was possible to collect rammed earth (Figure 4); the authorization of the building owner for the samples' collection and the geographic location of the buildings (three located in Leiria municipality and three in Pombal municipality). The GPS coordinates of those six buildings are presented in Table 2, which also shows the identification of the studied buildings and samples.

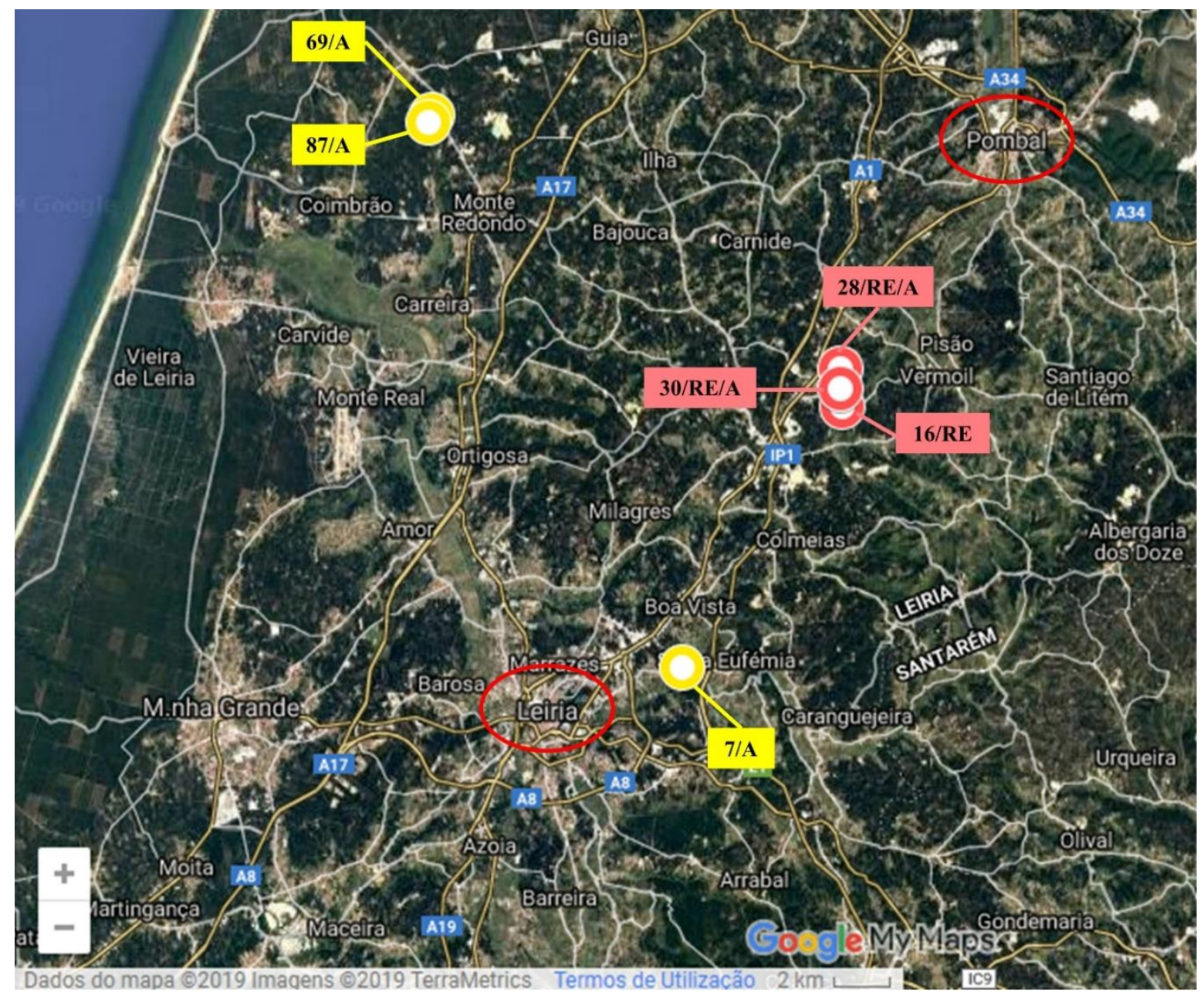

Figure 4. Map of the location of the six studied buildings: A - adobe masonry; RE - rammed earth; RE/A - presenting both construction techniques but where RE was sampled 
The process of collection of the adobe samples is illustrated in Figure 3 as all adobes were collected from the buildings using a chisel and a hammer, trying to choose adobes that were protected and not directly exposed to weathering. With regards to rammed earth samples, a similar process was performed.

Table 2. Identification of the buildings and of the samples collected

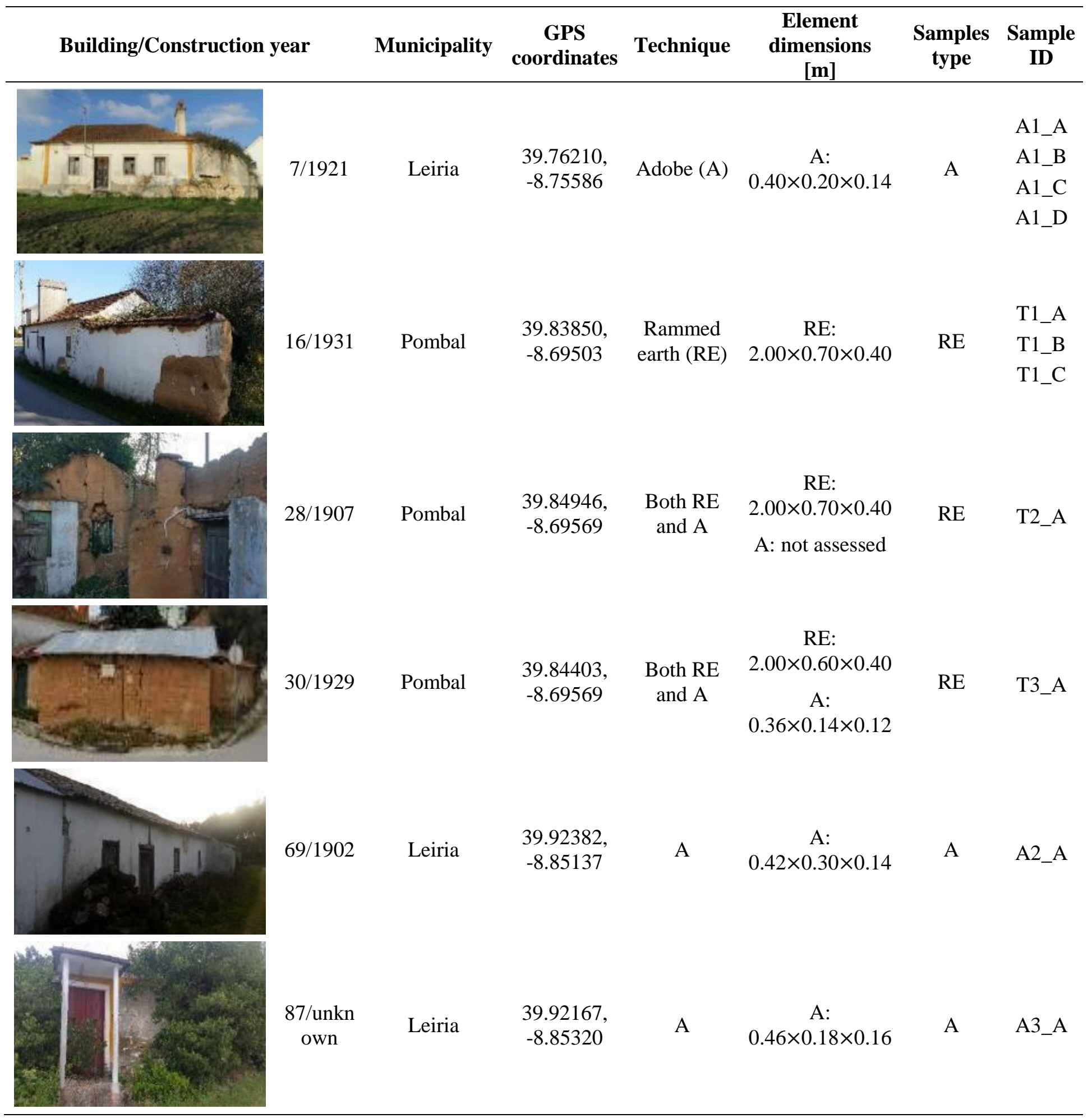


The OES were placed to dry in laboratory conditions (45-60\% relative humidity (RH) and 18$26{ }^{\circ} \mathrm{C}$ temperature) and previously used to perform apparent density, ultrasonic pulse velocity and thermal conductivity tests. After performing these non-destructive tests, OES were cut to produce sixty nine samples of smaller dimensions (SSD) to be used in the mechanical characterization (dry abrasion, tensile and compressive strength tests) (Table 3). The number of SSD tested for each building varies due to the size and number of OES collected (e.g. the total number of SSD tested for building 7 is higher than those tested for building 30 because it was possible to collect four OES from building 7 and just one from building 30, due to limitations imposed by the owners). Eighteen SSD were also obtained from the OES and used for capillary absorption and drying.

Table 3. Original (OES) and smaller dimensions (SSD) samples used for each test

\begin{tabular}{|c|c|c|c|c|c|c|c|}
\hline $\begin{array}{l}\text { Building / } \\
\text { Samples }\end{array}$ & $7 / \mathbf{A 1}$ & $16 / \mathrm{T} 1$ & 28 / T2 & 30 / T3 & 69 / A2 & 87 / A3 & Total \\
\hline OES & $\begin{array}{l}\text { A1_A } \\
\text { A1_B } \\
\text { A1_C } \\
\text { A1_D }\end{array}$ & $\begin{array}{l}\text { T1_A } \\
\text { T1_B } \\
\text { T1_C }\end{array}$ & T2_A & T3_A & A2_A & A3_A & 11 \\
\hline $\begin{array}{l}\text { SSD (tensile } \\
\text { flexural } \\
\text { strength) }\end{array}$ & $\begin{array}{l}\text { A1_AP1 } \\
\text { A1_AP2 } \\
\text { A1_BP1 } \\
\text { A1_BP2 }\end{array}$ & $\begin{array}{l}\text { T1_AP1 } \\
\text { T1_AP2 } \\
\text { T1_BP1 } \\
\text { T1_CP1 }\end{array}$ & $\begin{array}{l}\text { T2_AP1 } \\
\text { T2_AP2 } \\
\text { T2_AP3 }\end{array}$ & $\begin{array}{l}\text { T3_AP1 } \\
\text { T3_AP2 } \\
\text { T3_AP3 }\end{array}$ & $\begin{array}{l}\text { A2_AP1 } \\
\text { A2_AP2 } \\
\text { A2_AP3 }\end{array}$ & $\begin{array}{l}\text { A3_AP1 } \\
\text { A3_AP2 } \\
\text { A3_AP3 }\end{array}$ & \multirow{3}{*}{69} \\
\hline $\begin{array}{c}\text { SSD } \\
\text { (compressive } \\
\text { strength) }\end{array}$ & $\begin{array}{l}\text { A1_AC } \\
\text { A1_BC } \\
\text { A1_CC } \\
\text { A1_DC } \\
\text { A1_EC } \\
\text { A1_FC } \\
\end{array}$ & $\begin{array}{l}\text { T1_AC } \\
\text { T1_BC } \\
\text { T1_CC }\end{array}$ & $\begin{array}{l}\text { T2_AC } \\
\text { T2_BC } \\
\text { T2_CC } \\
\text { T2_DC }\end{array}$ & $\begin{array}{l}\text { T3_AC } \\
\text { T3_BC } \\
\text { T3_CC } \\
\text { T3_DC }\end{array}$ & $\begin{array}{l}\text { A2_AC } \\
\text { A2_BC } \\
\text { A2_CC }\end{array}$ & - & \\
\hline $\begin{array}{l}\text { SSD (dry } \\
\text { abrasion) }\end{array}$ & $\begin{array}{l}\text { A1_AP1_a } \\
\text { A1_AP1_b } \\
\text { A1_AP2_a } \\
\text { A1_AP2_b } \\
\text { A1_BP1_a } \\
\text { A1_BP1_b } \\
\text { A1_BP2_a } \\
\text { A1_BP2_b }\end{array}$ & $\begin{array}{l}\text { T1_AP1_a } \\
\text { T1_AP1_b } \\
\text { T1_AP2_a } \\
\text { T1_AP2_b } \\
\text { T1_BP1_a } \\
\text { T1_BP1_b } \\
\text { T1_CP1_a } \\
\text { T1_CP1_b }\end{array}$ & $\begin{array}{l}\text { T2_AP1_a } \\
\text { T2_AP1_b } \\
\text { T2_AP2_a } \\
\text { T2_AP2_b }\end{array}$ & $\begin{array}{l}\text { T3_AP1_a } \\
\text { T3_AP1_b } \\
\text { T3_AP1_c }\end{array}$ & $\begin{array}{l}\text { A2_AP1_a } \\
\text { A2_AP1_b } \\
\text { A2_AP1_c }\end{array}$ & $\begin{array}{l}\text { A3_AP1_a } \\
\text { A3_AP1_b } \\
\text { A3_AP1_c }\end{array}$ & \\
\hline
\end{tabular}




\begin{tabular}{|c|l|l|l|l|l|l|l|}
\hline Capillary & A1_a & T1_a & T2_a & T3_a & A2_a & A3_a & \\
absorption & A1_b & T1_b & T2_b & T3_b & A2_b & A3_b & 18 \\
and drying & A1_c & T1_c & T2_c & T3_c & A2_c & A3_c & \\
\hline
\end{tabular}

\subsection{Earth testing methods}

The quantification of the proportions of all size fractions composing the earth of the initial samples (after their disaggregation) was evaluated through dry particle size distribution, following LNEC Specification E196 (1966) using sieves from $63 \mathrm{~mm}$ to $0.075 \mathrm{~mm}$ opening. Coarse larger gravel was rare and was previously removed manually. The wet sieving, although much more precise because all the particles are disaggregated, was not performed due to limited material sampling.

The quick sedimentation test, allowing a qualitative determination of the earth particle size distribution by visual observation of the sedimentation layers (clay+silt, sand and gravel), was performed to complement the dry sieving. The test was conducted according to Standards Australia \& Walker (2002) and, as for dry sieving, coarse gravel was previously removed manually.

The mineralogical characterization of the fine fraction of the six earthen materials was made using X-ray diffraction (XRD), a technique that provides information about the minerals present in a sample in proportions higher than $2 \%$ to $4 \%$ by weight. The fine fraction was obtained from the particles liberated during the disaggregation of the samples and passing the $106-\mu \mathrm{m}$ sieve. The XRD was performed using a BruckerTM D8 Discover diffractometer with $40 \mathrm{kV}$ and 40 $\mathrm{mA} \mathrm{Cu} \mathrm{K} \alpha$ radiation, and a speed of $0.05^{\circ} / \mathrm{s}$ from $3^{\circ}$ to $75^{\circ}(2 \theta)$. DIFFRAC.SUITE EVA software was used to compare the experimental peaks with the ICDD database.

\subsection{Samples testing methods}

Table 4 presents the laboratory tests performed and the test procedures used to assess the physico-mechanical properties of the adobe and rammed earth samples. It is important to 
mention that these tests can only be used as quality indicators of the tested samples, and not of the masonry or wall itself (NTE E.80, 2017).

Table 4. Laboratory tests performed to assess the physico-mechanical properties of the earthen samples

\begin{tabular}{ll}
\hline Test & Reference \\
\hline Bulk density & DIN 18945 (2013b) and UNE 41410 (2008) \\
Ultrasonic pulse velocity & LNEC FE Pa 43 (2016) \\
Thermal conductivity & Equipment manual \\
Compressive strength & NTE E.080 (2017) and Standards Australia \& Walker (2002) \\
Tensile flexural strength & Standards Australia \& Walker (2002) \\
Dry abrasion & DIN 18947 (2013) \\
Capillary absorption & LNEC FE Pa 40 (2016), DIN 18945 (2013b) and UNE 41410 \\
& $(2008)$ \\
Drying & EN 16322 (2013) \\
\hline
\end{tabular}

The bulk density of each OES was determined by the ratio between the mass and the volume of the samples.

Non-destructive ultrasonic pulse velocity testing was performed indirectly, on the surface of the samples, using a Pundit Lab equipment with two transducers of $54 \mathrm{kHz}$. The test consists of measuring the wave propagation time between a transmitter and a receiver placed at a known distance, with the final objective of assessing the compactness and the rigidity of the samples under analysis (Bernat-Maso et al., 2017). The existence of anomalies in the samples, like voids, fractures, poor homogenization or low compactness, will origin a lower wave propagation time. The tests were performed on the OES considering three different measuring points $(10 \mathrm{~cm}, 15$ $\mathrm{cm}$ and $20 \mathrm{~cm}$ ) in relation to the point $0 \mathrm{~cm}$.

Thermal conductivity testing was performed using a heat transfer analyzer ISOMET 2014 and a $60 \mathrm{~mm}$ diameter contact probe API 210416 with a measurement range of $0.3-2.0 \mathrm{~W} /\left(\mathrm{m}^{\circ} \mathrm{C}\right)$ for all OES. The samples were placed on a $5 \mathrm{~cm}$ thick polystyrene panel to avoid heat dissipation and the tests were performed with the samples in laboratory equilibrium conditions with a temperature of $20 \pm 2^{\circ} \mathrm{C}$ and a relative humidity (RH) of $65 \pm 5 \%$. 
The tensile flexural strength was determined in 10 rammed earth SSD and 10 adobe SSD (Table 3) through flexural tests. The OES were cut in SSD with length dimensions varying between 28 $\mathrm{cm}$ and $44 \mathrm{~cm}$, width varying from $13.5 \mathrm{~cm}$ to $16 \mathrm{~cm}$ and height from $11 \mathrm{~cm}$ to $15 \mathrm{~cm}$. Not all the specimens were cut with the same size due to the OES dimensions constraints. The test was carried out in a bench press with a load cell of $50 \mathrm{kN}$ and a test speed of $1.5 \mathrm{~mm} / \mathrm{min}$. The failure load was taken as the maximum load. The tensile strength of homogeneous materials was obtained in $\mathrm{N} / \mathrm{mm}^{2}$ and calculated using Equation 1:

$$
f_{t}=\frac{3 \times l \times F}{2 \times b \times H^{2}}
$$

in which 1 is the distance between the supports ( $\mathrm{mm})$, taken as $150 \mathrm{~mm}, \mathrm{~F}$ is the maximum load $(\mathrm{N}), \mathrm{b}$ is the width of the sample (mm) and $\mathrm{H}$ is its height $(\mathrm{mm})$.

Compressive strength tests were carried out on 11 SSD rammed earth samples with $100 \mathrm{~mm} \times$ $100 \mathrm{~mm} \times 100 \mathrm{~mm}($ NTE E.80, 2017) from buildings 16, 28 and 30 and on 9 SSD adobe samples from buildings 7 and 69, using the same bench press, load cell and loading speed as for the flexural strength tests. Due to lack of samples with appropriate size, it was not possible to submit adobe samples collected from building A3 to this type of tests. The compressive strength $\left(\mathrm{N} / \mathrm{mm}^{2}\right)$ was obtained by the ratio between the maximum load applied $(\mathrm{N})$ and the compression $\operatorname{area}(100 \mathrm{~mm} \times 100 \mathrm{~mm})$.

Dry abrasion resistance was determined measuring the weight loss of each sample after 20 rotations of a polyethylene brush $(70 \mathrm{~mm}$ in diameter) applied to its surface with a pressure of 2 $\mathrm{kg}$. The final objective of the test is to assess the sample surface resistance and the eventual need of surface protection (Röhlen and Ziegert, 2011). The test was only performed on one of the sample's faces, being chosen the most regular one.

Capillary absorption and drying tests were conducted in a conditioned room $\left(20 \pm 2^{\circ} \mathrm{C}\right.$ and $65 \pm 5 \%$ $\mathrm{RH})$ in samples that resulted from the cuts that have been made to produce the smaller samples for mechanical tests (Figure 5). Thus, the dimension of the samples was variable and CAD 
software was used to measure the exact area of the face that was exposed to water. All the samples presented a relatively low height and their lateral faces were not waterproof (Figure 5A). Each sample was placed into a net basket to be handled throughout the test avoiding damaging the sample (Faria et al., 2015), on top of a tissue to retain fine particles. During the test, the samples were kept in contact with $2 \mathrm{~mm}$ height of water (Figure 5B, where not all the samples were completely saturated). The mass of the samples was measured at given time intervals to record the mass increase due to water absorption.

After 48 hours of capillary absorption the samples were put to dry (Figure 5C) and weighted after determined periods of time. EN 16322 (2013) standard refers two distinct drying phases: DR1 - the first drying phase, calculated by the negative slope of the initial linear section of the drying curve plotted with time in abscissa; and DR2 - the second drying phase, calculated by the negative slope of the linear section of the drying curve plotted against the square root of time in abscissa.

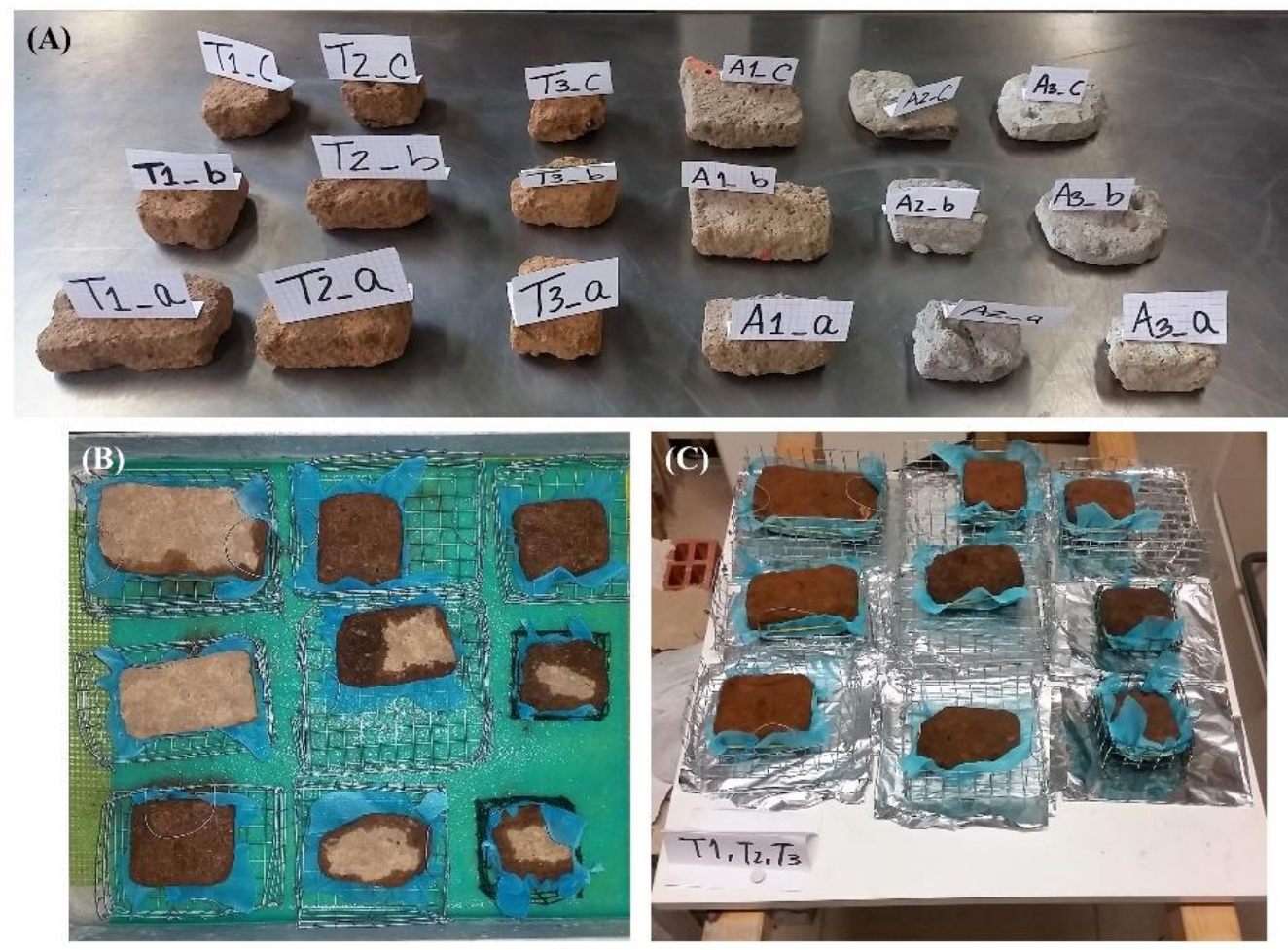

Figure 5. Samples of smaller dimensions (SSD) before the capillary absorption test (A); some samples during the capillarity test (B) and the drying test (C) 


\section{Results and discussion}

\subsection{Dry particle size distribution, quick sedimentation and XRD}

Figure 6 shows the dry particle size distribution curves of the earth materials.

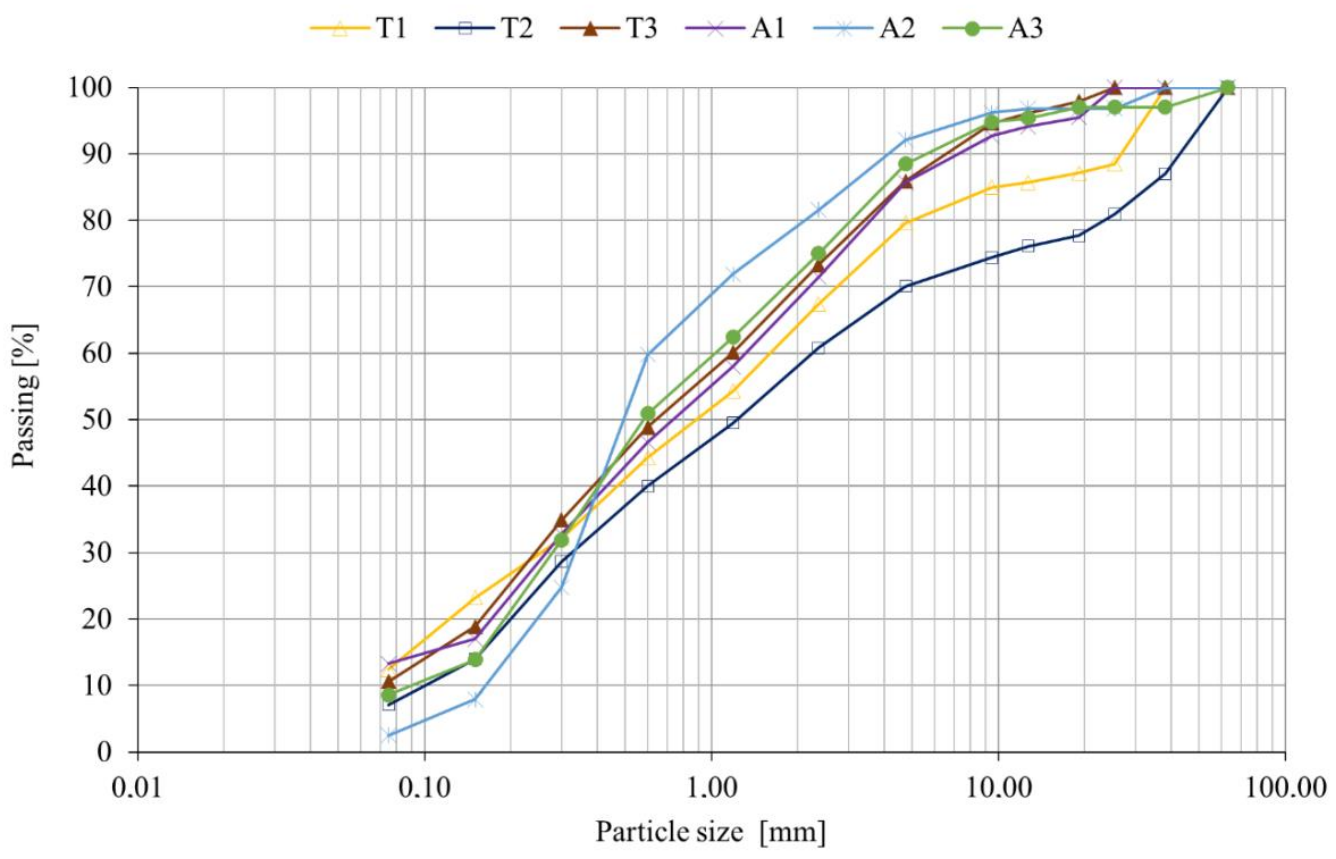

Figure 6. Particle size distribution of the 11 rammed earth and adobe samples collected in situ

Based on knowledge of the authors on earthen techniques and previous studies, it was expected to have a more pronounced difference between rammed earth and adobe samples particle size distribution. Particularly T3 rammed earth sample presents a particle size distribution showing that it would have been possible to produce adobe with the same earth. Therefore, that shows that the decision of using the local earth to produce rammed earth or adobe in Leiria region was at least not always conditioned by the local earth particle size. Nevertheless, it is possible that the earth used for both techniques has been previously sieved. That was particularly usual for adobe production.

Results of quick sedimentation test are presented in Table 5. They are very similar to those previously obtained in the dry particle size distribution test. Rammed earth walls in the region of Leiria present aggregates of large granulometry, agglutinated by the clay (and silt), while 
adobe samples present higher percentages of clay and silt and few coarse granular materials, being the latter mostly constituted by sand.

Table 5. Results of the sedimentation test for all earthen materials

\begin{tabular}{cccc}
\hline Sample & Clay + Silt $\mathbf{( \% )}$ & Sand $(\boldsymbol{\%})$ & Fine gravel $(\boldsymbol{\%})$ \\
\hline T1 & 12 & 55 & 33 \\
T2 & 13 & 48 & 39 \\
T3 & 11 & 62 & 27 \\
A1 & 7 & 58 & 29 \\
A2 & 3 & 79 & 18 \\
A3 & 9 & 66 & 25 \\
\hline
\end{tabular}

The results of XRD are summarized in Table 6. It can be observed that quartz, feldspar and muscovite are the predominant minerals both in the earthen materials from Pombal and Leiria. The mineralogical composition of the rammed earth samples is very similar; only kaolinite was not found in T3. Adobe samples slightly differ in terms of presence of kaolinite and tosudite (a 1:1 regular interstratification of a chlorite group mineral and a smectite group mineral). Nevertheless, the differences between the mineralogical characterization of the rammed earth and adobe materials are not significant.

Table 6. Mineralogical composition of the fine fraction of the earthen samples obtained by XRD

\begin{tabular}{ccccccc}
\hline Sample/Crystalline compound & Quartz & Feldspar & Kaolinite & Muscovite & Clinochlore & Tosudite \\
\hline T1 & +++ & ++ & $\operatorname{Trc} /+$ & $+/++$ & Trc & - \\
T2 & +++ & ++ & $\operatorname{Trc} /+$ & ++ & Trc & - \\
T3 & +++ & $+/++$ & - & $++/+++$ & Trc & - \\
A1 & +++ & Trc/+ & $\operatorname{Trc}$ & + & $?$ & - \\
A2 & +++ & Trc/+ & - & $+/++$ & $?$ & + \\
A3 & +++ & Trc/+ & Trc/+ & + & + & - \\
\hline
\end{tabular}

Notation: (?) - doubts on the presence; (Trc) - traces; (-) - not detected; $(+)$ - low proportion; $(++)$ intermediate proportion; (+++) high proportion.

It is important to note that both adobe and rammed earth were not stabilized with lime, which is frequent in other cases of vernacular earthen constructions. That was preliminarily assessed by 
placing the samples inside water and verifying their disintegration after a short period of time and later on confirmed by the XRD results.

\subsection{Bulk density and ultrasonic pulse velocity}

Table 7 presents the results of the physical and mechanical characterization of the samples analyzed. The rammed earth samples bulk density ranges between $1360 \mathrm{~kg} / \mathrm{m}^{3}$ and $1790 \mathrm{~kg} / \mathrm{m}^{3}$, with an average of $1553 \mathrm{~kg} / \mathrm{m}^{3}$. The unusual lower bulk density of sample T2 may be justifiable by the poor state of conservation of the rammed earth wall from which the sample was extracted (Table 2) and also by constraints in assessing the precise sample dimension due to its particularly irregular shape. Silva et al. (2016) simulated rammed earth samples in the laboratory with earth from Odemira, south of Portugal, and obtained slightly higher results of bulk density while Gomes et al. (2019) obtained even higher results for rammed earth samples collected in old buildings in Alentejo (Table 1). Adobe samples present values ranging between $1400 \mathrm{~kg} / \mathrm{m}^{3}$ and $1730 \mathrm{~kg} / \mathrm{m}^{3}$, with an average of $1527 \mathrm{~kg} / \mathrm{m}^{3}$. Silveira et al. (2013), although for air lime stabilized adobe from Aveiro region, obtained values in the same range (Table 1).

Table 7. Global average results of the physical and mechanical characterization of rammed earth and adobe samples

\begin{tabular}{|c|c|c|c|c|c|c|}
\hline \multirow[b]{2}{*}{ Buildings } & \multicolumn{3}{|c|}{ Rammed earth } & \multicolumn{3}{|c|}{ Adobe } \\
\hline & 16 & 28 & 30 & 7 & 69 & 87 \\
\hline Samples & T1 & T2 & T3 & $\mathbf{A 1}$ & $\mathbf{A 2}$ & A3 \\
\hline Bulk density $\left(\mathrm{kg} / \mathrm{m}^{3}\right)$ & $1510 \pm 110$ & $1360 \pm 40$ & $1790 \pm 280$ & $1730 \pm 60$ & $1400 \pm 50$ & $1450 \pm 30$ \\
\hline $\begin{array}{l}\text { Ultrasonic pulse } \\
\text { velocity }(\mathrm{m} / \mathrm{s})\end{array}$ & $874.6 \pm 147.1$ & $609.5 \pm 70.1$ & $475.2 \pm 131.7$ & $921.1 \pm 262.7$ & $339.4 \pm 46.8$ & $272.5 \pm 36.5$ \\
\hline $\begin{array}{l}\text { Thermal conductivity } \\
{[\mathrm{W} /(\mathrm{m} . \mathrm{K})]}\end{array}$ & $0.54 \pm 0.04$ & $0.48 \pm 0.05$ & $0.48 \pm 0.02$ & $0.69 \pm 0.13$ & $0.42 \pm 0.01$ & $0.41 \pm 0.04$ \\
\hline $\begin{array}{l}\text { Compressive strength } \\
\left(\mathrm{N} / \mathrm{mm}^{2}\right)\end{array}$ & $0.44 \pm 0.17$ & $0.74 \pm 0.26$ & $0.73 \pm 0.19$ & $1.06 \pm 0.22$ & $0.69 \pm 0.35$ & - \\
\hline $\begin{array}{l}\text { Tensile strength } \\
\left(\mathrm{N} / \mathrm{mm}^{2}\right)\end{array}$ & $0.19 \pm 0.03$ & $0.12 \pm 0.01$ & $0.11 \pm 0.03$ & $0.27 \pm 0.08$ & $0.11 \pm 0.03$ & $0.09 \pm 0.03$ \\
\hline $\begin{array}{l}\text { Mass loss by dry } \\
\text { abrasion }(\mathrm{g})\end{array}$ & $9.7 \pm 2.2$ & $8.6 \pm 2.3$ & $18.6 \pm 9.9$ & $18.3 \pm 7.1$ & $12.7 \pm 7.1$ & $10.9 \pm 2.4$ \\
\hline
\end{tabular}


Capillary absorption

coeff. $\left[\mathrm{kg} /\left(\mathrm{m}^{2} \cdot \mathrm{min}^{1 / 2}\right)\right]$

Drying rate phase 1

$\left[\mathrm{kg} /\left(\mathrm{m}^{2} . \mathrm{h}\right)\right]$

Drying rate phase 2

$\left.\left[\mathrm{kg} / \mathrm{m}^{2} . \mathrm{h}\right)\right]$

$$
1.35 \pm 0.34
$$

$1.42 \pm 0.36$

$1.14 \pm 0.33$

$0.69 \pm 0.08$

$0.77 \pm 0.40$

$0.68 \pm 0.03$

$0.11 \pm 0.01$

$0.14 \pm 0.02$

$0.12 \pm 0.01$

$0.11 \pm 0.02$

$0.10 \pm 0.01$

$0.15 \pm 0.03$

$0.49 \pm 0.06$

$0.59 \pm 0.02$

$0.53 \pm 0.03$

$0.40 \pm 0.05$

$0.40 \pm 0.04$

$0.61 \pm 0.08$

The ultrasonic pulse velocity (UPV) results of the adobe samples follow the bulk density trend with a significant correlation $\left(\mathrm{r}^{2}=0.95\right)$ as presented in Figure 7A. The same behavior is not observed for rammed earth samples (Figure 7B).

The lowest values of UPV were obtained for adobe samples A2 and A3. Apart from adobe sample A1, all rammed earth samples show higher UPV values, which is in agreement with the fact of rammed earth being a compacted earthen material.

(A)

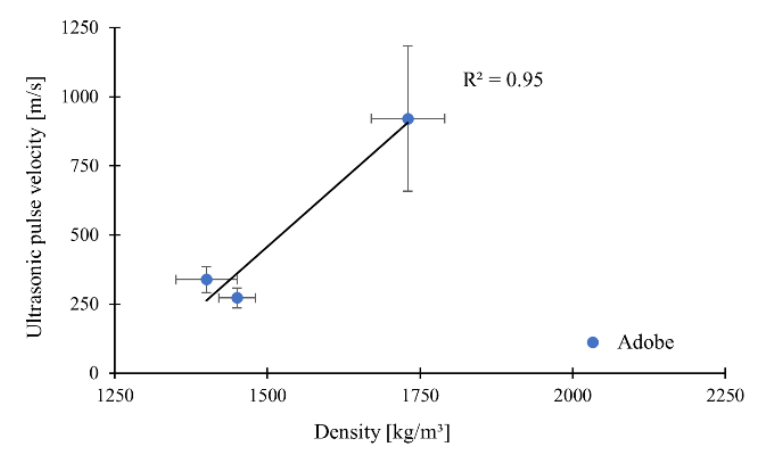

(B)

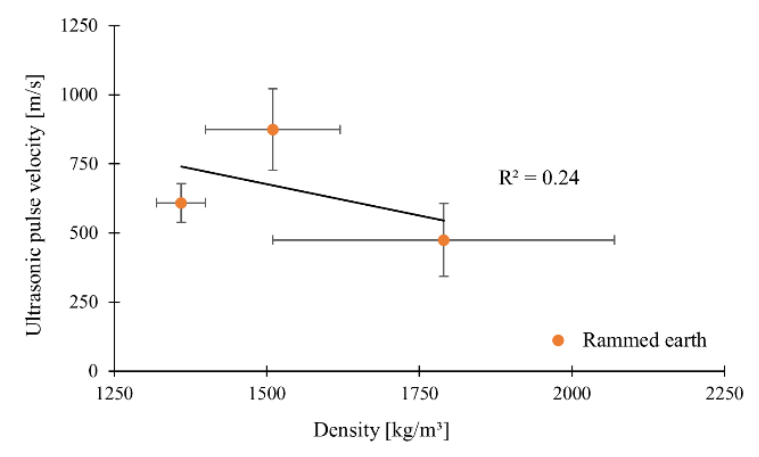

Figure 7. Correlation between ultrasonic pulse velocity and bulk density for adobe (A) and for rammed earth samples (B)

\subsection{Thermal conductivity}

From Table 7, it can be observed that sample $\mathrm{T} 1$ has a slightly higher result of thermal conductivity $(0.54 \mathrm{~W} /(\mathrm{m} . \mathrm{K}))$ than the other two rammed earth samples. The same happens with the adobe samples, with A1 presenting the highest thermal conductivity result $(0.69 \mathrm{~W} /(\mathrm{m} . \mathrm{K}))$. In fact, these are expected results since those two samples (A1 and T1) had already presented the highest results of UPV. Figure 8 shows the correlations between UPV and thermal conductivity and between bulk density and thermal conductivity, indicating high correlations in 
both cases. However, the correlation obtained between bulk density and thermal conductivity for rammed earth samples (Figure 8B) only considers the T1 and T2 samples, since T3 sample was excluded.
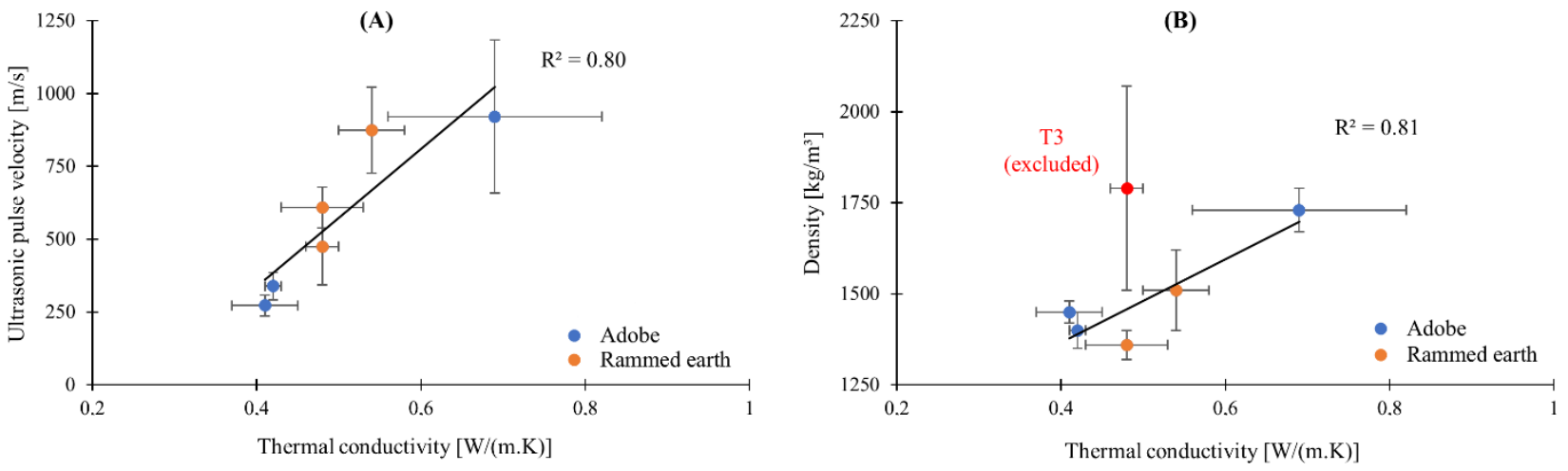

Figure 8. Correlations between UPV and thermal conductivity (A) and bulk density and thermal conductivity (B)

Abanto et al. (2017) studied the thermal properties of adobes in order to improve the buildings performance in Peru by maximizing the hygrothermal properties of this material. The results of thermal conductivity obtained varied from $0.330 \mathrm{~W} /(\mathrm{m} . \mathrm{K})$ to $0.255 \mathrm{~W} /(\mathrm{m} . \mathrm{K})$. These values are lower than those found in this study but are justified by high fibers content. Nevertheless, Pina dos Santos and Matias (2006) define $1.1 \mathrm{~W} /(\mathrm{m} . \mathrm{K})$ as the value of thermal conductivity that should be considered for earthen constructive elements (adobe, rammed earth and compressed earth blocks). In the absence of any other information, this value should be adopted by Portuguese thermal legislation. Notwithstanding, the results obtained in the present research are much lower, probably due to the irregularity of the samples surface which may have reduced the effective contact area of the probe.

Without considering the plasters and renders, the thermal transmittance value (U) of T2 rammed earth walls, $0.40 \mathrm{~m}$ thick and a thermal conductivity $(\lambda)$ of $0.48 \mathrm{~W} /(\mathrm{m} . \mathrm{K})$, is $1.00 \mathrm{~W} /\left(\mathrm{m}^{2} . \mathrm{K}\right)$; for A3 adobe masonry walls, $0.46 \mathrm{~m}$ thick and a $\lambda$ of $0.41 \mathrm{~W} /(\mathrm{m} . \mathrm{K})$, is $0.77 \mathrm{~W} /\left(\mathrm{m}^{2} . \mathrm{K}\right)$. These are high U values even for thermal legislation of Mediterranean countries. Thermal conductivity of 
earth elements is very important to be considered in retrofitting actions in earthen buildings, although it is not the only important thermal characteristic to be taken into account. For instance, in Mediterranean regions, the advantages of applying thermal insulation on earth walls retrofitting are frequently less than the disadvantages that this action will bring to the building as a whole. Earth is one of the construction materials with higher hygroscopic behavior, due to the clay particles, and higher thermal inertia, due to the high mass of the walls (McGregor et al., 2014). An eco-efficient heating device (such as a woodstove) for winter, and night cooling optimization in summer, may be enough to control the RH and temperature of the indoor air, improving comfort. That indoor comfort can only be correctly studied by dynamic simulation, which is not currently used by designers. Nevertheless, in the vernacular earth dwellings it will be extremely important to apply thermal and acoustic insulation on the roof, usually with a wooden structure.

\subsection{Compressive and tensile flexural strengths}

The results of compressive strength (Table 7) present an average value of $0.64 \mathrm{~N} / \mathrm{mm}^{2}$ for rammed earth and $0.88 \mathrm{~N} / \mathrm{mm}^{2}$ for adobe. From previous studies it was expected that rammed earth samples presented higher strength than adobe since the latter were not compacted. In fact, average and standard deviation results gathered in Table 1 for unstabilized rammed earth samples and lime stabilized adobe collected in old buildings are $1.44 \pm 0.73 \mathrm{~N} / \mathrm{mm}^{2}$ and $1.03 \pm 0.68 \mathrm{~N} / \mathrm{mm}^{2}$, respectively. An opposite trend is verified in this study, with adobe samples presenting compressive strength similar (sample A2 $-0.69 \mathrm{~N} / \mathrm{mm}^{2}$ ), and even higher (sample A1 - 1.06 $\mathrm{N} / \mathrm{mm}^{2}$ ), than rammed earth samples. Nevertheless, the standard deviation of the results gathered in Table 1 is very high. Therefore, further characterization of earthen rammed earth and adobe samples is needed to validate tendencies.

A low compressive strength was not expected for samples $\mathrm{T} 1\left(0.44 \mathrm{~N} / \mathrm{mm}^{2}\right)$, since the ultrasonic pulse velocity indicated that this material appeared to be more compact, more homogeneous and less porous. Although T1 samples presented a dry particle size distribution that is intermediate 
between T2 and T3 (the former with higher content on coarser aggregates) and a clay+silt content that is quantitatively also intermediate, it can be justified by the high heterogeneity that rammed earth samples collected from old buildings might have. The compressive strength is influenced by the proportion of aggregates (from large to fine size) and the clay matrix acts as a natural binder agglutinating those aggregates.

Previous experimental results indicated similar values of compressive strength for lime stabilized adobes from Aveiro (Silveira et al., 2013) and higher values of compressive strength for unstabilized rammed earth prepared in the laboratory using soil from Odemira, Alentejo (Silva et al., 2016), as can be observed in Table 1. Guillaud (1995) considers that a rammed earth element should have a minimum compressive strength of $1.0 \mathrm{~N} / \mathrm{mm}^{2}$ while Standards Australia \& Walker (2002) states that this minimum should be increased to $2.0 \mathrm{~N} / \mathrm{mm}^{2}$. The results obtained for rammed earth samples in the present study are far from the values recommended by these authors. Nevertheless, it is important to notice that they were taken from real buildings, most of them abandoned, with more than 75 years old, and in some cases with the earth walls unprotected and exposed to weathering for a long time. Therefore, it can be said that the walls show a good mechanical durability after a long period in service.

High heterogeneity on compressive strength results has been also found in other studies. Air lime stabilized adobes collected by Coroado et al. (2010) from several Aveiro buildings presented compressive strength between $0.41 \mathrm{~N} / \mathrm{mm}^{2}$ and $1.44 \mathrm{~N} / \mathrm{mm}^{2}$ (with an average value of 0.65 $\mathrm{N} / \mathrm{mm}^{2}$ ), while Figueiredo et al. (2013) obtained a compressive strength of $0.46 \mathrm{~N} / \mathrm{mm}^{2}$ in adobes from a demolition site in Aveiro (Table 1). These results are in the same range or even lower than the results obtained for unstabilized adobe in the present study.

Silva et al. (2018) performing compressive strength tests on samples representative of the rammed earth material of walls using soil from the region of Esposende, Portugal, found slightly lower average results than those obtained in the study performed with rammed earth samples from Odemira (Table 1), though higher than those of the present study. 
The results of tensile flexural strength (Table 7) show that sample T1 presents the highest value among the rammed earth samples $\left(0.19 \mathrm{~N} / \mathrm{mm}^{2}\right)$, while A1 has the highest value for adobe samples $\left(0.27 \mathrm{~N} / \mathrm{mm}^{2}\right)$. Considering the remaining samples (T2, T3, A2 and A3), lower values of tensile strength were obtained, which can be explained by the presence of internal fissures in the material probably caused by the cutting process of the samples.

The results of tensile and compressive strengths are correlated with the results of the ultrasonic pulse velocity (Figure 9). However, the correlation obtained between compressive strength and ultrasonic pulse velocity for all samples (Figure 9B) only considers the T2 and T3 rammed earth samples, since T1 sample was excluded.
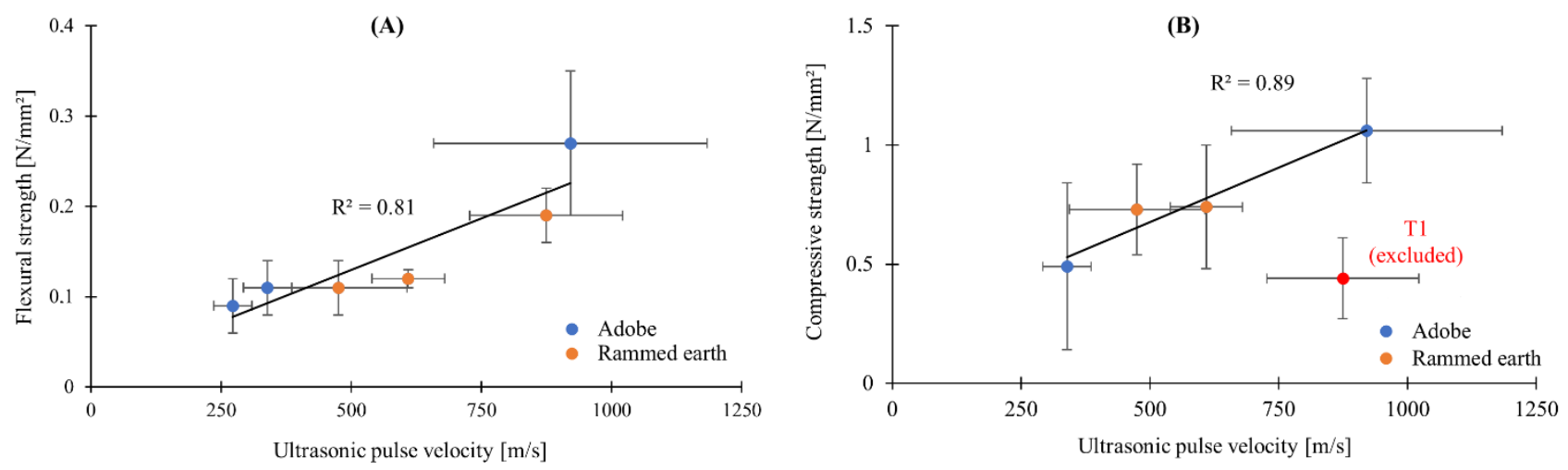

Figure 9. Correlations between UPV and flexural strength (A) and UPV and compressive strength (B)

Previous experimental data (Table 1) showed similar results of tensile strength for adobes collected in Aveiro (Silveira et al., 2012; Silveira et al., 2013; Figueiredo et al, 2013). No results were found in the literature for tensile strength regarding rammed earth samples collected in situ. Silva et al. (2016) obtained higher values of tensile strength, but for rammed earth samples prepared in the laboratory with soil collected from Odemira (Table 1).

\subsection{Dry abrasion}

The results of weight loss by dry abrasion test (Table 7) show that samples T3 and A1 have the highest mass losses, a result that was not expected considering that they also had higher bulk 
density and compressive strength, when compared to the other samples of rammed earth and adobe, respectively. The lower mass loss by abrasion of T2 samples may be due to the fact that these samples presented a higher clay content, inferred by XRD and quick sedimentation tests. A similar tendency was noticed by Lima et al. (2016) when testing the influence of sand particle size on the abrasion resistance of an earth plaster: a lower resistance was provided by the formulation with finer sand in comparison with coarser sand. Anyway, most of the samples show high mass losses. This fact reinforces the importance of providing appropriate protection to the earth walls through the use of compatible renders and plasters. In the region of Leiria, the survey made allowed to infer that most of the earthen walls were protected by renders and plasters. However, this situation is different when the buildings are used as storehouses; in this case, most of them have the walls unprotected.

The average mass losses due to dry abrasion obtained for rammed earth in the present study are similar to those obtained by Faria et al. (2015) for earth mortars. Therefore, for instance indoors, an earth plaster can be applied and act as a sacrificial plaster, protecting the wall surface without jeopardizing compatibility with that wall.

\subsection{Capillary absorption and drying}

The results of capillary absorption and drying tests are presented in Figures 10, 11 and 12 and in Table 7. The analysis of the results allowed concluding that the water absorption process is quick, which is in accordance with the sensitivity of earth materials to water. Although it was not possible to reach total saturation of the samples, to assure they would not start to lose material, an asymptotic value was almost reached after approximately two days (Figure 10). 


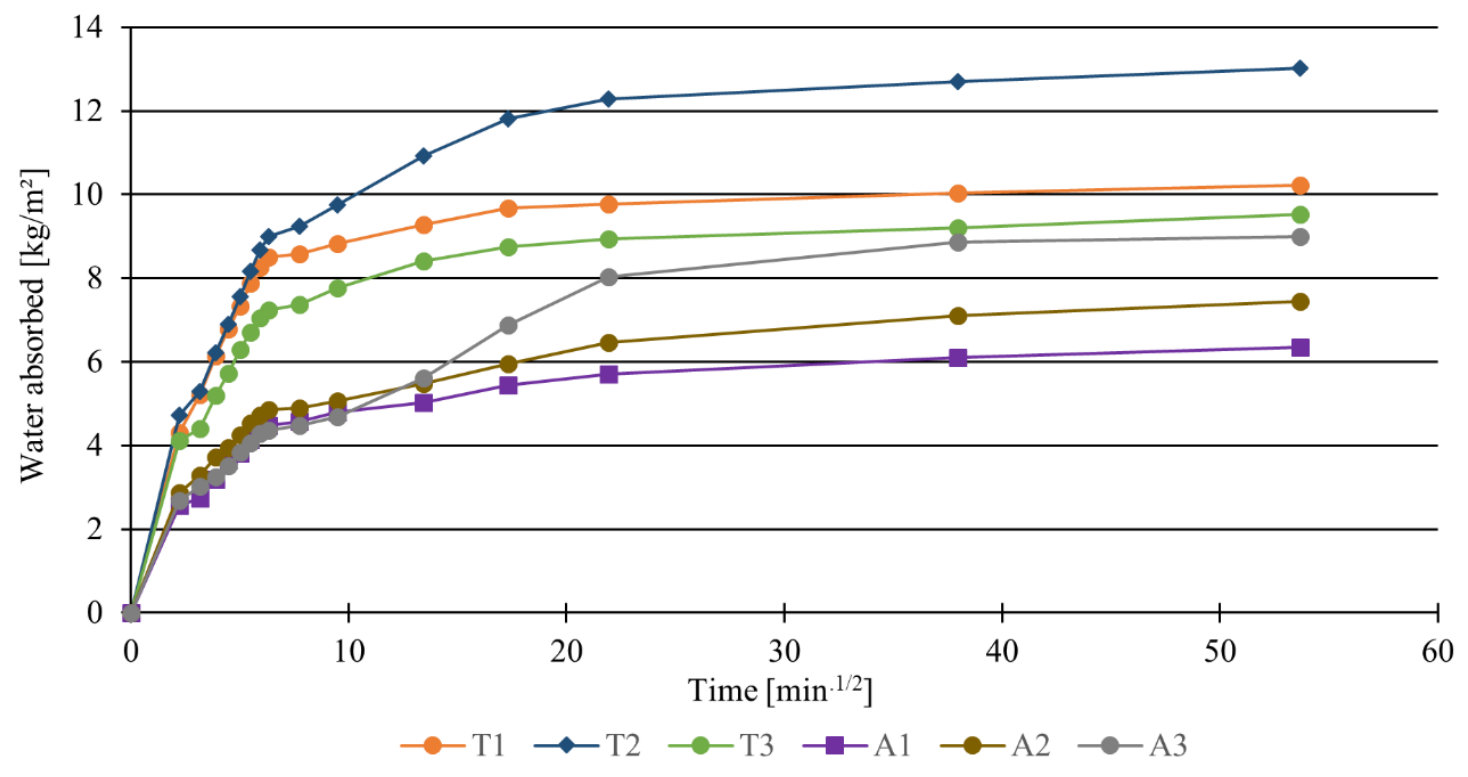

Figure 10. Capillary absorption curves

Concerning adobe, all the samples present similar capillary coefficients: A2 shows the highest capillary coefficient $\left(0.77 \mathrm{~kg} /\left(\mathrm{m}^{2} \cdot \mathrm{min}^{1 / 2}\right)\right)$ and A3 the lowest $\left(0.68 \mathrm{~kg} /\left(\mathrm{m}^{2} \cdot \mathrm{min}^{1 / 2}\right)\right)$. Comparing the two construction techniques, the adobe samples absorbed less water and at a much slower rate than rammed earth samples.

Drying curves showing the two distinct drying phases are presented in Figure 11 (DR1) and Figure 12 (DR2) while drying rates are presented in Table 7. The test of A3 present the highest value of DR1 with $0.15 \mathrm{~kg} /\left(\mathrm{m}^{2} . \mathrm{h}\right)$ while the lowest value is obtained for A2 $\left(0.10 \mathrm{~kg} /\left(\mathrm{m}^{2} \cdot \mathrm{h}\right)\right)$. Considering the second phase of drying, A3 also present the highest value $\left(0.61 \mathrm{~kg} /\left(\mathrm{m}^{2} . \mathrm{h}\right)\right)$ and A1 and A2 share the lowest DR2 $\left(0.40 \mathrm{~kg} /\left(\mathrm{m}^{2} . \mathrm{h}\right)\right)$. In adobes, a direct correlation between rate of absorption and drying is not visible, with the specimens of A2 having the highest absorption and the lowest drying rates, while in the rammed earth specimens this correlation seems to exist (Table 7). It is also important to notice that the rammed earth materials showed significantly higher capillary absorption coefficient than adobes but similar drying behavior. That should probably be justified by the porous structure of the rammed earth, with more capillary pores due to compaction process in comparison to the adobe. Nevertheless, only representative pore size 
distribution results could confirm this supposition, which is not easy to achieve due to the reduced size of samples commonly used for porosimetry tests.

Figure 13A shows the correlation between the first and the second drying rates and Figure 13B the correlation between capillary absorption and drying. It is very interesting to note that although rammed earth samples present higher values of capillary absorption than adobe samples, both present similar values of bulk density (e.g. samples T3 and A1 and samples T2 and A2 have similar results of bulk density but rammed earth samples (T3 and T2) always present higher capillary absorption). This fact may induce that the type of construction technique used (adobe and rammed earth) influences the results of capillary absorption, even when elements have similar values of density. Thus, considering both construction techniques the correlation obtained between capillary absorption and density is very low $\left(r^{2}=0.03\right)$.

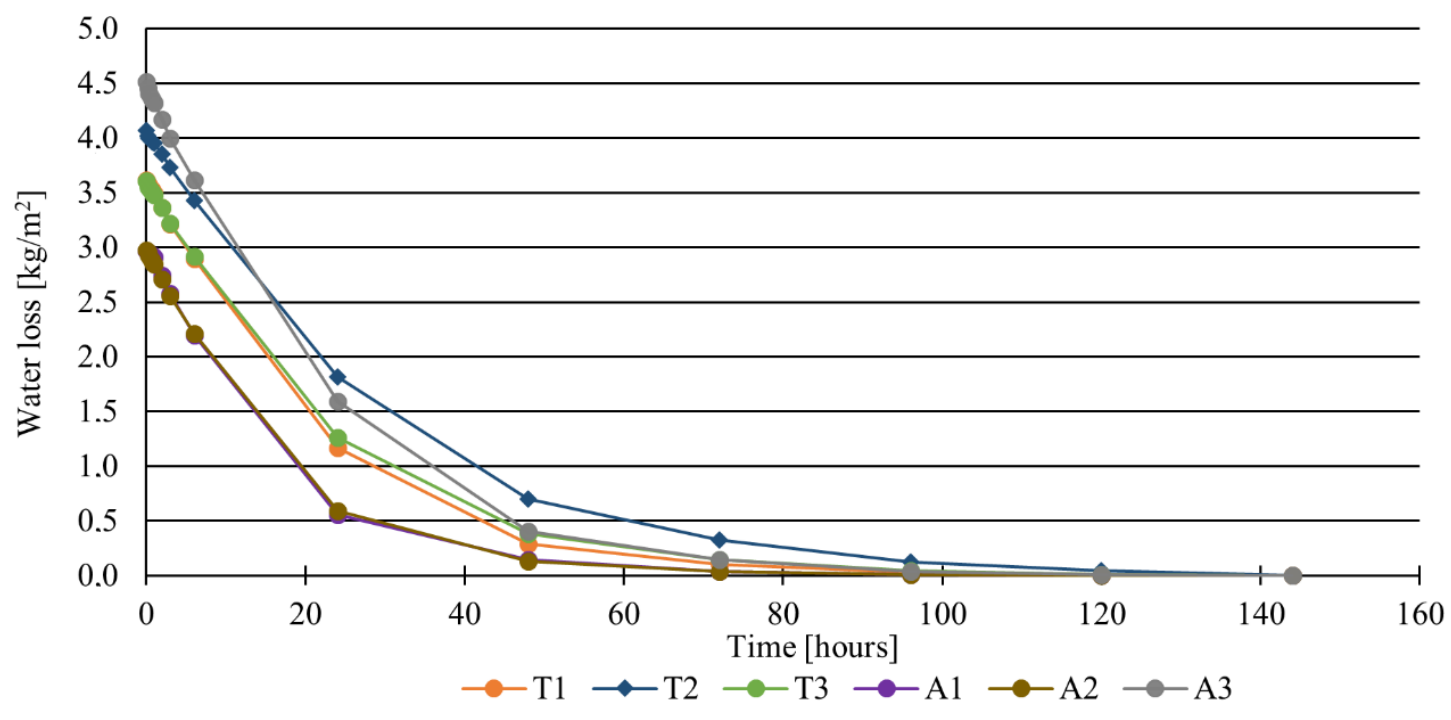

Figure 11. Drying curves for DR1 determination by initial segment slope 


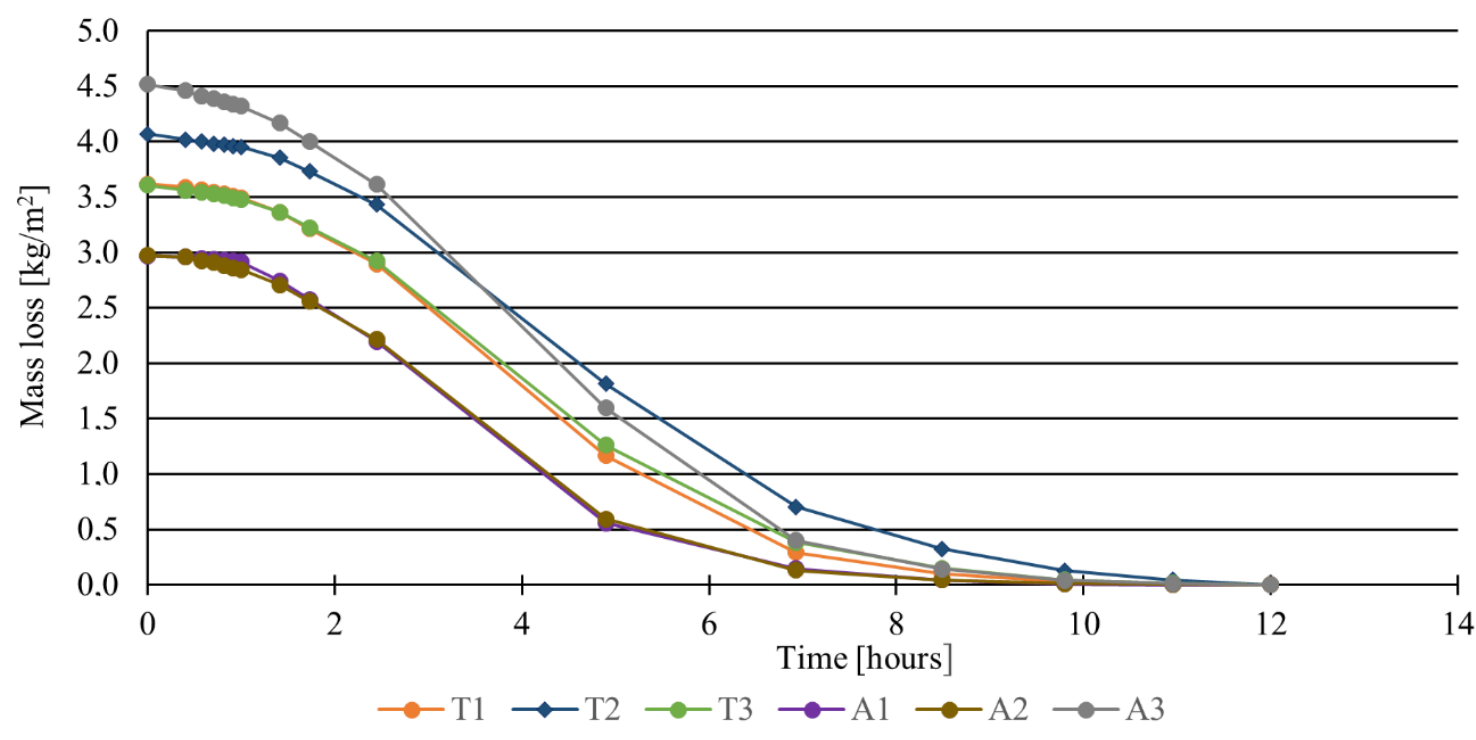

Figure 12. Drying curves for DR2 determination by the intermediate linear segment slope
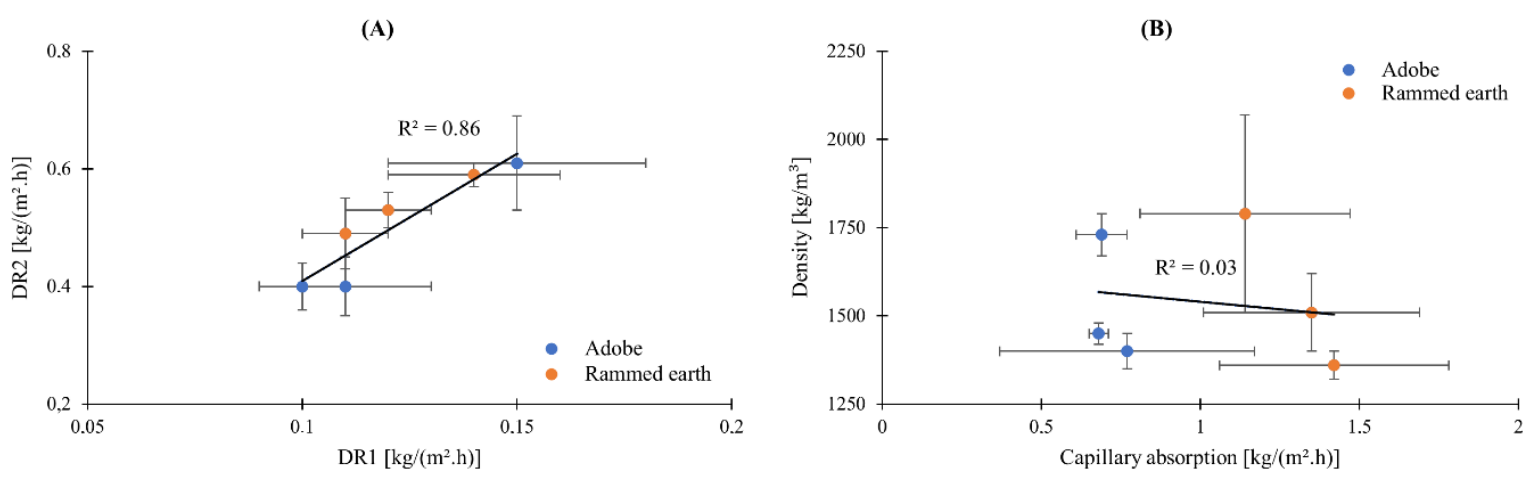

Figure 13. Correlations between DR1 and DR2 (A) and between capillary absorption and bulk density (B)

The fact that the capillary water absorption coefficient is high, mainly for rammed earth samples, and the drying rates are also high, is quite positive and leads to the conclusion that these earthen materials can easily dissipate water that accesses the walls. Protective renders and paint systems should not eliminate this capability. These renders should be based on lime-earth mortars, to assure compatibility with the earthen walls but acceptable durability (Mateus et al., 2016). 


\section{Conclusions}

Several vernacular earthen buildings were assessed in Leiria region, central Portugal, using rammed earth, adobe masonry or both techniques. No characterization of earthen materials from this region was found in previous studies. It was possible to collect eleven samples, with different sizes, from six of those buildings. The samples were tested with the original size for apparent density, ultrasound pulse velocity and thermal conductivity and after being cut into smaller dimensions for compressive and tensile flexural strengths, dry abrasion as well as capillary absorption and drying. In the present paper, the results of an experimental campaign of characterization of these samples are presented and discussed. The results obtained allow supporting the presentation of proposals for future interventions. The main conclusions are the following:

- Based on thermal conductivity of the adobe and rammed earth samples from Leiria's district, U-values of the corresponding walls are high in comparison with nowadays thermal comfort standards for Mediterranean countries, namely for Portugal. Nevertheless, to express the thermal comfort, hygroscopic behavior and thermal inertia should also be considered. In the studied vernacular dwellings, more important than insulating the walls will be to insulate the roof, install a heat source for winter and optimize night cooling in summer period;

- From previous studies, it was expected a higher compressive strength for rammed earth samples than for adobe. In this work that was not verified, and even slightly higher values were obtained for adobe samples, although without statistical significance due to the reduced number of samples that was possible to collect and test. In average, adobe samples present higher strength than rammed earth samples. Previous experimental results (Table 1) indicated similar or lower compressive and tensile flexural strengths for adobes of Aveiro, even though these adobes were lime-stabilized. Concerning the compressive and flexural strengths of rammed earth samples, significantly higher values were obtained for samples prepared in laboratory with soil collected from Odemira, Alentejo, which is common due to a more 
effective compactness process. Nevertheless, laboratory produced rammed earth samples were not submitted to natural aging as it is the case of the samples of the present study, which probably justifies the results obtained. In fact, unstabilized rammed earth and particularly adobe masonry are vulnerable to water, due to the transport of clayish fine particles of the earthen materials to the surface. Therefore, a compatible and efficient render should be applied and maintained to protect the old vernacular earthen walls;

- The capillary water absorption coefficient was high mainly for rammed earth samples, but the drying rates were also high, which is quite positive and leads to the conclusion that these earthen materials can easily dissipate water accessing the walls. The application of protective renders and plasters should not jeopardize this capacity;

- Mass losses by dry abrasion for both adobe and rammed earth samples were similar to those usually presented by earth mortars. Therefore, a surface protection by compatible plasters and renders, respectively earthen-based and air lime-based, should be strongly encouraged to enlarge the walls durability.

The compilation of all the characterization results into an open access database will be the next step. This data will be available to support future compatible, effective and reversible interventions in vernacular earthen buildings, not only from Leiria region, but also from other buildings with similar characteristics, contributing to their conservation and retrofitting.

\section{Disclosure}

No potential conflict of interest was reported by the authors.

\section{Funding/Acknowledgements}

The authors acknowledge the support of Fundação para a Ciência e Tecnologia (FCT), Portugal for funding José Lima's scholarship (SFRH/BD/119703/2016), as well as the research project PTDC/EPH-PAT/4684/2014: DB-Heritage - Database of building materials with historical and 
heritage interest. Dr. José Mirão and Ing. Inês Oliveira are also acknowledged for the XRD characterization.

\section{ORCID}

João Luís Parracha - https://orcid.org/0000-0001-6214-3400

José Lima - http://orcid.org/0000-0002-1377-8570

Maria Teresa Freire - https://orcid.org/0000-0001-9402-0501

Paulina Faria - http://orcid.org/0000-0003-0372-949X

\section{References}

Abanto GA, Karkri M, Lefebvre G, Horn M, Solis, JL and Gómez, MM. 2017. Thermal properties of adobe employed in Peruvian rural areas: Experimental results and numerical simulation of a traditional bio-composite material. Case Studies in Construction Materials 6:177-191. http://dx.doi.org/10.1016/j.cscm.2017.02.001

Allinson D and Hall M. 2010. Hygrothermal analysis of a stabilised rammed earth test building in the UK. Energy and Buildings 42:845-852. https://doi.org/10.1016/j.enbuild.2009.12.005

Bernat-Maso E, Teneva E, Escrig C and Lluís EG. 2017. Ultrasound transmission method to assess raw earthen materials. Construction and Building Materials 156:555-564. http://dx.doi.org/10.1016/j.conbuildmat.2017.09.012

Correia M. 2004. Islamic fortresses in military rammed earth. Pedra \& Cal 24:16 (in Portuguese).

Coroado J, Paiva H, Velosa A and Ferreira VM. 2010. Characterization of renders, joint mortars and adobes from traditional constructions in Aveiro (Portugal). International Journal of Architectural Heritage, 4(2):102.-114. https://doi.org/10.1080/15583050903121877

Costa CS, Rocha F, Varum H and Velosa A. 2013. Influence of the mineralogical composition on the properties of adobe blocks from Aveiro, Portugal. Clay Minerals, 48:749-758. https://doi.org/10.1180/claymin.2013.048.5.07 
Costa C, Cerqueira A, Rocha F and Velosa A. 2018. The sustainability of adobe construction: past to future. International Journal of Architectural Heritage. https://doi.org/10.1080/15583058.2018.1459954

DIN 18947. 2013a. - Earth plasters - Terms and definitions, requirements, test methods, Deutsches Institut für Normung, Berlin (in German).

DIN 18945. 2013b. - Earth blocks - Terms and definitions, requirements, test methods, Deutsches Institut für Normung, Berlin (in German).

EN 16322. 2013. Conservation of Cultural Heritage - Test methods - Determination of drying properties, CEN, Brussels.

Faria P, Silva V, Pereira C and Rocha M. 2012. The monitoring of rammed earth experimental walls and characterization of rammed earth samples. Rammed Earth Conservation, Mileto, Vegas \& Cristini (eds.), Taylor \& Francis Group, London, 91-97.

Faria P, Santos T and Aubert JE. 2015. Experimental characterization of an earth eco-efficient plastering mortar. Journal of Materials in Civil Engineering 28(1):04015085-1/9. https://doi.org/10.1061/(ASCE)MT.1943-5533.0001363

Faria-Rodrigues P. 2005. Rendering of raw earth walls. Earth Architecture in Portugal (M.Fernandes, M.Correia, eds.). Lisboa, Argumentum, 68-73.

Ferreira M, Lima J, Freire T, Faria P. 2017. Adobe masonry and rammed earth dwellings in Leiria region, Portugal. A material and documental survey with a view to their conservation and rehabilitation. CREPAT 2017, A. Costa, A. Velosa, A. Tavares (Eds.), Universidade de Aveiro (in Portuguese).

Figueiredo A, Varum H, Costa A, Silveira D and Oliveira C. 2013. Seismic retrofitting solution of an adobe masonry wall. Materials and Structures, 46:203-219. https://doi.org/10.1617/s11527-012-9895-1 
Gomes MI, Faria P and Gonçalves TD. 2019. Rammed earth walls repair by earth-based mortars: the adequacy to assess effectiveness. Construction and Building Materials 205:213-231. https://doi.org/10.1016/j.conbuildmat.2019.01.222

Guillaud H. 1995. Dominio del material tierra y desarrollo de su potencialidades arquitectónicas. CRATerre-EAG, Holguín, Cuba (in Spanish).

Hamard E, Cazacliu B, Razakamanantsoa A and Morel J. 2016. Cob, a vernacular earth construction process in the context of modern sustainable building. Building and Environment 106:103-119. http://dx.doi.org/10.1016/j.buildenv.2016.06.009

Houben H and Guillaud H. 1994. Earth Construction - a Comprehensive guide, CRATerre EAG. Intermediate Technology Publications, London.

Lima J, Correia D, Faria P. 2016. Earth plasters: the influence of gypsum addition and sand particle size. Argamassas 2016 - II Simpósio de Argamassas e Soluções Térmicas de Revestimento, Coimbra (in Portuguese).

LNEC E196. 1966. Particle size analysis (by dry sieving and sedimentation). National Laboratory for Civil Engineering, Lisbon (in Portuguese).

LNEC FE Pa 40.1. 2016. Test procedure for wall renders - Capillary absorption test for irregular and friable samples, Lisbon (in Portuguese).

LNEC FE Pa 43.1. 2016. Test procedure for wall renders - Mechanical testing by ultrasounds, Lisbon (in Portuguese).

Maniatidis V and Walker P. 2003. A review of rammed earth construction. DTi Partners in Innovation Project 'Developing Rammed Earth for UK Housing'. University of Bath, Bath.

Mateus L, Veiga MR and Brito J. 2015 In situ characterization of rammed earth wall renders. International Journal of Architectural Heritage, 9(4):430-442. https://doi.org/10.1080/15583058.2013.798714 
Mateus L, Veiga MR, de Brito J. 2016. Characterization of ancient external renderings and the use of pre-mixed replacement renderings in rammed earth constructions in the Algarve. TERRA 2016 - XII World Congress on Earthen Architecture, Lyon, France.

McGregor F, Heath A, Fodde E and Shea A. 2014. Conditions affecting the moisture buffering measurement performed on compressed earth blocks. Building and Environment, 75:11-18. https://doi.org/10.1016/j.buildenv.2014.01.009

McHenry PG. 1989. Adobe and Rammed Earth Buildings: Design and Construction. University of Arizona Press, Arizona.

NTE E.080. 2017. Reglamento nacional de construcciones. Norma técnica de edificación Adobe. Sencico. Lima (in Spanish).

Parracha JL, Santos Silva A, Cotrim M, Faria P. 2019. Mineralogical and microstructural characterisation of rammed earth and earthen mortars from 12th century Paderne Castle. Journal of Cultural Heritage, https://doi.org/10.1016/j.culher.2019.07.021

Pina dos Santos, C and Matias L. 2006. Thermal transmission value for buildings envelope elements. ITE 50. National Laboratory for Civil Engineering, Lisbon (in Portuguese).

Silva RA, Oliveira DV, Schueremans L, Miranda T and Machado J. 2016. Effectiveness of the repair of unstabilised rammed earth with injection of mud grouts. Construction and Building Materials, 127:861-871. https://doi.org/10.1016/j.conbuildmat.2016.10.064

Silva RA, Mendes N, Oliveira DV, Romanazzi A, Domínguez-Marínez O and Miranda T. 2018. Evaluating the seismic behavior of rammed earth buildings from Portugal: From simple tools to $\begin{array}{lllll}\text { advanced } & \text { approaches. } & \text { Engineering } & \text { Structures, } & 157,\end{array}$ https://doi.org/10.1016/j.engstruct.2017.12.021

Silveira D, Varum H, Costa A, Martins, T, Pereira H and Almeida J. 2012. Mechanical properties of adobe bricks in ancient constructions. Construction and Building Materials, 28:36-44. https://doi.org/10.1016/j.conbuildmat.2011.08.046 
Silveira D, Varum H and Costa A. 2013. Influence of the testing procedures in the mechanical characterization of adobe bricks. Construction and Building Materials, 40:719-728. https://doi.org/10.1016/j.conbuildmat.2012.11.058

Standards Australia \& Walker P. 2002. HB195-2002: The Australian earth building handbook. Standards Australia, Sydney.

UNE 41410. 2008. Bloques de tierra comprimida para muros y tabiques. Definiciones, especificaciones y métodos de ensayo, AENOR, Madrid (in Spanish). 